\title{
Energy Demand Analysis and Design of a Hybrid Power System in Bawean Islands, Indonesia
}

\author{
Ridho Hantoro ${ }^{1}$, Cahyun Budiono ${ }^{1}$, Ronald Kipkoech Ketter $^{2}$, and Nyoman Ade Satwika ${ }^{1 *}$ \\ ${ }^{1}$ Department of Physics Engineering, Faculty of Industrial Technology, Sepuluh Nopember Institute \\ of Technology, Surabaya, Indonesia, Indonesia, ITS Street, Sukolilo, Surabaya 60111. \\ ${ }^{2}$ Departement of Physics, Faculty of Mathematics and Science, Carl von Ossietzky Univesity \\ Oldenburg F.R. 26129, Germany
}

\begin{abstract}
Over 70000000 people in Indonesia have no access to electricity. This study was carried out in Bawean Islands which are located in the Java Sea about $150 \mathrm{~km}$ North of Surabaya, the headquarters of East Java. The study to determine the energy services available in the Bawean Island was done through interviewing a random sample of 72 households in two villages namely Komalasa and Lebak. Based on the average monthly electricity consumption of the sampled households connected to the grid, a hybrid renewable energy based electrical supply system was designed for Gili Timur Island, one of the satellite islands around Bawean Island. The system was designed with the aid of a time step simulation software used to design and analyze hybrid power systems. A sensitivity analysis was also carried out on the optimum system to study the effects of variation in some of the system variables. HOMER suggests that for the expected peak load of $131 \mathrm{~kW}$, an optimum system will consist of $150 \mathrm{~kW}$ from PV array, two wind turbines each rated $10 \mathrm{~kW}$, a $75 \mathrm{~kW}$ diesel generator and batteries for storage.
\end{abstract}

Key words: Bawean Island, HOMER, sustainable energy, renewable energy, hybrid power systems

\section{Introduction}

Over 70000000 people in Indonesia do not have access to electricity while over $40 \%$ of households still rely on traditional biomass for cooking. Around 165000 premature deaths in Indonesia [1] can be attributed to the use of traditional biomass due to the indoor air pollution resulting in respiratory diseases in mainly children and women. Bawean Island is located in the Java Sea approximately $150 \mathrm{~km}$ North of Surabaya, the capital of East Java province [1]. Administratively, it is part of Gresik regency and is made up of two subdistricts namely Sangkapura and Tambak. Bawean Island is about $15 \mathrm{~km}$ in diameter and has an area of $197 \mathrm{~km}^{2}$ [2]. It has a population of over 116000 [3]. A household survey was conducted to obtain current energy consumption data and patterns with the aid of a

* Corresponding author: nyomanadee@gmail.com 
questionnaire. This was achieved by choosing a random sample of 72 households in two villages in Sangkapura sub-district [1], Bawean Island and interviewing them through a set of open-ended and closed-ended questions as developed in the pre-designed questionnaire. A simple random sampling method was adopted in choosing the household surveyed. Among the households sampled, 36 were connected to the electricity service provider (PLN Bawean) grid while the other 36 were not connected to the grid.

The data obtained from the study was then analyzed mainly through the use of MS Excel and Hybrid Optimization Model for Electric Renewables (HOMER) software. MS Excel was used for statistical analysis of the data such as frequency distribution, comparison analysis, among others [4]. While HOMER was used to design and analyze an optimal hybrid electrical power system design based on conventional and locally available renewable energy sources [5] that could be exploited for the provision of sustainable electricity supply in Gili Timur Island.

It is a desire to see that the people living in Gili Timur Island enjoy electricity services just like the residents of main Bawean Island. There is also need for the electricity supply to be more reliable, sustainable and cleaner as compared to that of the main island. It is for this reason that this research used the current average electricity consumption demand from the neighbor Bawean Island in the design of the hybrid power system for Gili Timur Island. This research proposed design envisages a hybrid electrical supply system consisting of both renewable and conventional energy sources for environmental and economic sustainability in this paper.

\section{Background}

\subsection{Energy situation in Indonesia}

For a long time, the Indonesian economy has relied on oil as the main source of primary energy. However, the decrease in the output of oil as a result of maturing of oil wells and the decreased investment in new exploration as well as the increase in domestic consumption has led to policymakers diversifying to other primary sources available such as coal, biofuels and natural gas [6]. Coal and gas are being fronted as the best primary energy substitutes for generation of electricity while biofuels will play a bigger role in the diversification of transport fuel [7]. Table 1 and show the distribution of primary energy supply by source and the final energy supply by type respectively for the year. Crude oil accounts for about $39 \%$ of the primary energy supply while biomass accounts for $18 \%$ [8].

Currently, the renewable energy sources that are being focused on are geothermal, hydro, solar and wind. Geothermal and large hydro projects are being developed mainly for the central grid while small hydro, solar and wind energy projects are geared towards meeting the needs of the small and mostly remote islands [9]. The potential of the renewable sources in the country as estimated by the Ministry of Energy and Mineral Resources is as shown in Table 2. Hydro, geothermal and biomass have great potential with only a small proportion having been developed. 
Table 1. Primary energy supply by sources [8].

\begin{tabular}{|l|c|c|}
\hline Source & $\begin{array}{c}\text { Barrel of } \\
\text { Oil } \\
\text { Equivalent } \\
\text { (BOE) }\end{array}$ & Percentage Share \\
\hline Coal & $334 \times 10^{6}$ & $22 \%$ \\
\hline Crude Oil & $592 \times 10^{6}$ & $39 \%$ \\
\hline Natural Gas & $262 \times 10^{6}$ & $17 \%$ \\
\hline Hydropower & $31 \times 10^{6}$ & $2 \%$ \\
\hline Geothermal & $16 \times 10^{6}$ & $1 \%$ \\
\hline Biomass & $280 \times 10^{6}$ & $18 \%$ \\
\hline Total & $1516 \times 10^{6}$ & $100 \%$ \\
\hline
\end{tabular}

Table 2. Renewable energy sources [8].

\begin{tabular}{|l|l|l|}
\hline Source & Potential & $\begin{array}{l}\text { Installed } \\
\text { Capacity }\end{array}$ \\
\hline Hydro Power & $75.7 \mathrm{GW}$ & $4.2 \mathrm{GW}$ \\
\hline Geothermal & $28.5 \mathrm{GW}$ & $1.2 \mathrm{GW}$ \\
\hline $\begin{array}{l}\text { Mini/Micro } \\
\text { Hydro }\end{array}$ & $500 \mathrm{MW}$ & $86.1 \mathrm{MW}$ \\
\hline Biomass & $49.8 \mathrm{GW}$ & $445 \mathrm{MW}$ \\
\hline Solar & $4.8 \mathrm{kWh} / \mathrm{m}^{2} / \mathrm{d}$ & $14.1 \mathrm{MW}$ \\
\hline Wind & $3 \mathrm{~m} / \mathrm{s}$ to $6 \mathrm{~m} / \mathrm{s}$ & $1.4 \mathrm{MW}$ \\
\hline
\end{tabular}

One of the incentives that have been used by the government to encourage the development of renewable energy technologies in Indonesia has been through the use of feed-in-tariffs [10]. The renewable energy sources have different feed-in-tariffs depending on the source of energy, installed capacity and the region where the installation is taking place. A summary of the feed-in-tariffs based on Ministerial Regulations. The tariff also varies depending on whether the plant is connected to a low voltage or medium voltage network [11].

\subsection{Energy situation in Bawean Island}

Bawean Island has its electricity being supplied by PLN Bawean. PLN Bawean has a centralized power generation consisting of 11 diesel generators with an installed capacity of 5.35 MW. Eight of the diesel engines rated 4.2 MW [6] are owned by private companies subcontracted by PLN and are always in operation. The remaining $1.15 \mathrm{MW}$, consisting of three diesel engines, are owned by PLN and are on standby and can be brought online in the event of a breakdown in any of those from the private company. According to PLN Bawean statistics, the peak demand in the island currently stands at 3.76 MW. PLN Bawean has a $20 \mathrm{kV}$ transmission grid circumnavigating the island and supplying the load centers located along grid. The electrification ratio based on the number of households connected to the PLN grid is $79 \%$ according to PLN Bawean data for September 2013 [12]. It can be observed from these data that whereas household consumers (social and residential categories) consume $75 \%$ of the generated electricity, they only contribute to $71 \%$ of the revenue [13]. This is attributed to the lower tariffs charged for these customer categories compared to other categories. 
Most of the households that are not connected to PLN grid depend on small diesel generators for their electricity needs. The households that own small generators of capacity between $2.4 \mathrm{kVA}$ and $5 \mathrm{kVA}$ of which they tend to supply electricity to their neighbors at a fee based on the number of electrical loads in the household [10].

\section{Energy demand analysis in Bawean Island}

\subsection{Methodology and general sample characteristics}

These two villages were chosen because of ease of accessibility. Which, 36 of the randomly sampled households were from grid-connected sub-villages called Komalasa and Tanjung Anyar while the other 36 were from non grid connected sub-villages called Sumur-Sumur and Gunung Mas. The fact that the village elders had been informed of our coming beforehand by the head of the Sangkapura sub-district made our work easy. The total number of people in the surveyed households was 316 giving an average of four people per household. This average is slightly more than that of the official data from the government for the island which puts the average at approximately four people per household.

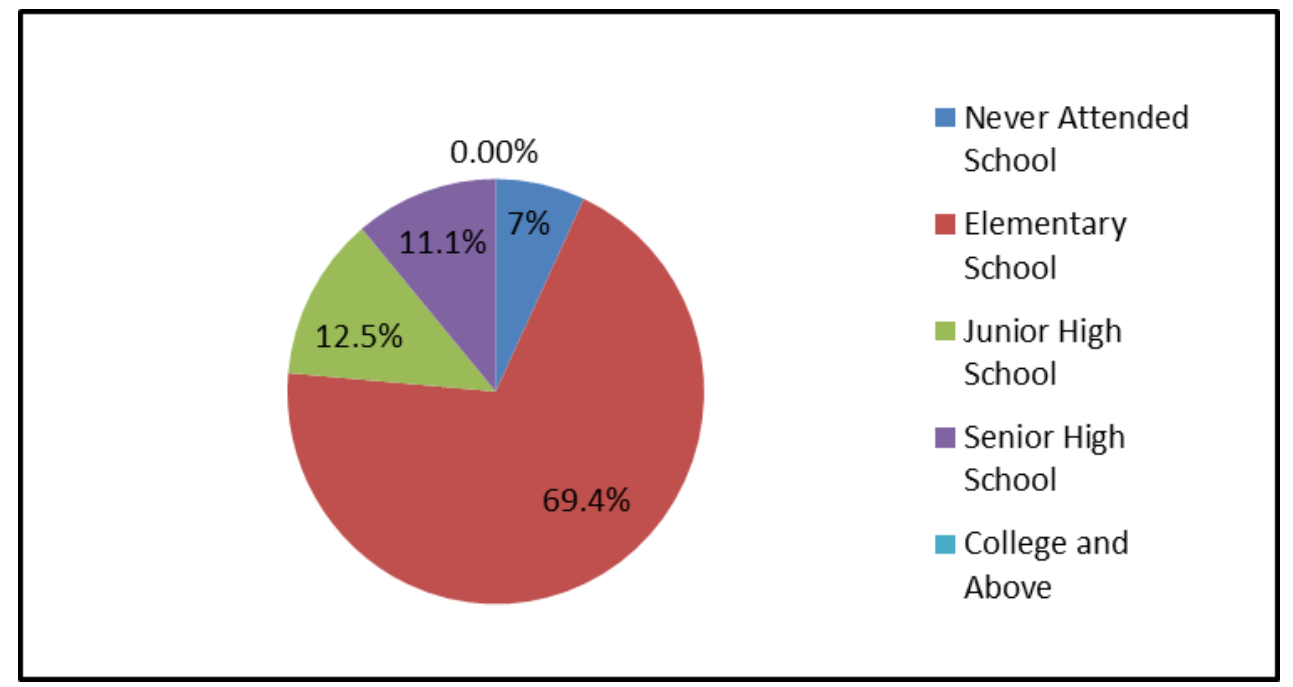

Fig. 1. Overal education level distribution of the respondents.

The overall distribution of the respondents by their level of education is shown in Figure 2. The literacy rate from the surveyed respondents was $93 \%$ which is comparable to those of the national literacy rates according to the government which puts it at $93.25 \%$ [8] 


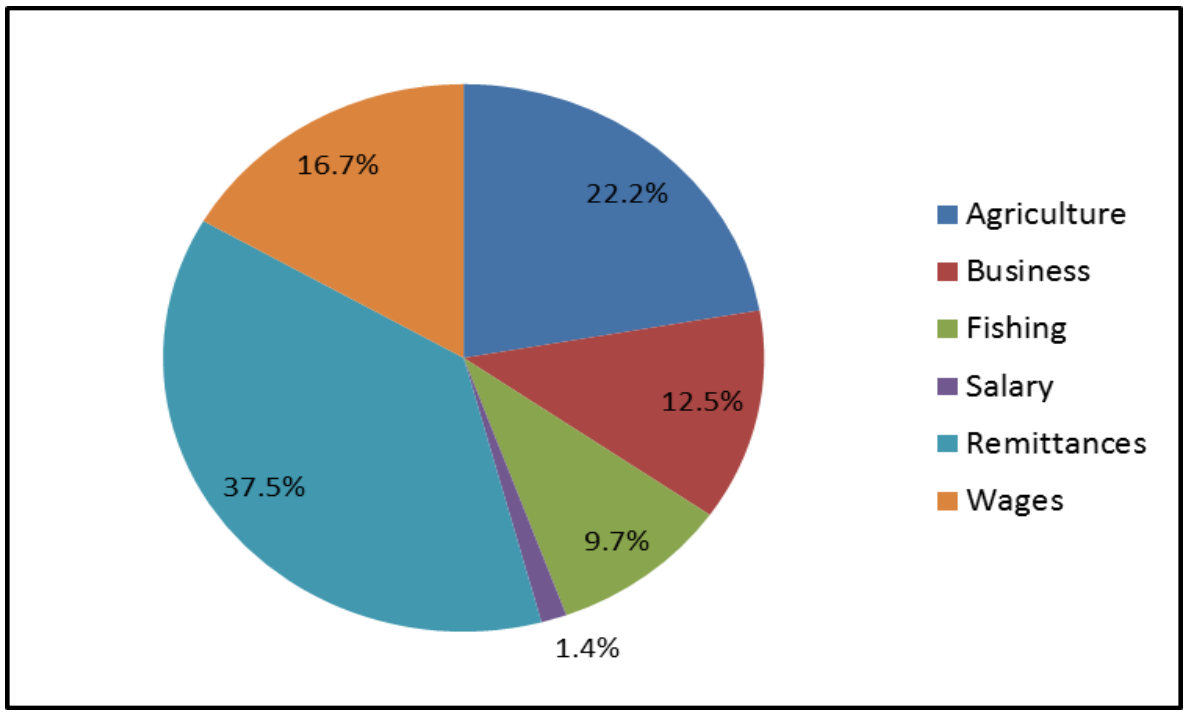

Fig. 2. Distribution of main source of income.

More than one to third of the respondents had their primary source of income is remittances from relatives working abroad. This shows the strong dependence of residents of Bawean Island on remittances. The other main sources of household income were wages, business, fishing, and salary. Figure 3 shows the distribution of main sources of income in the sampled households.

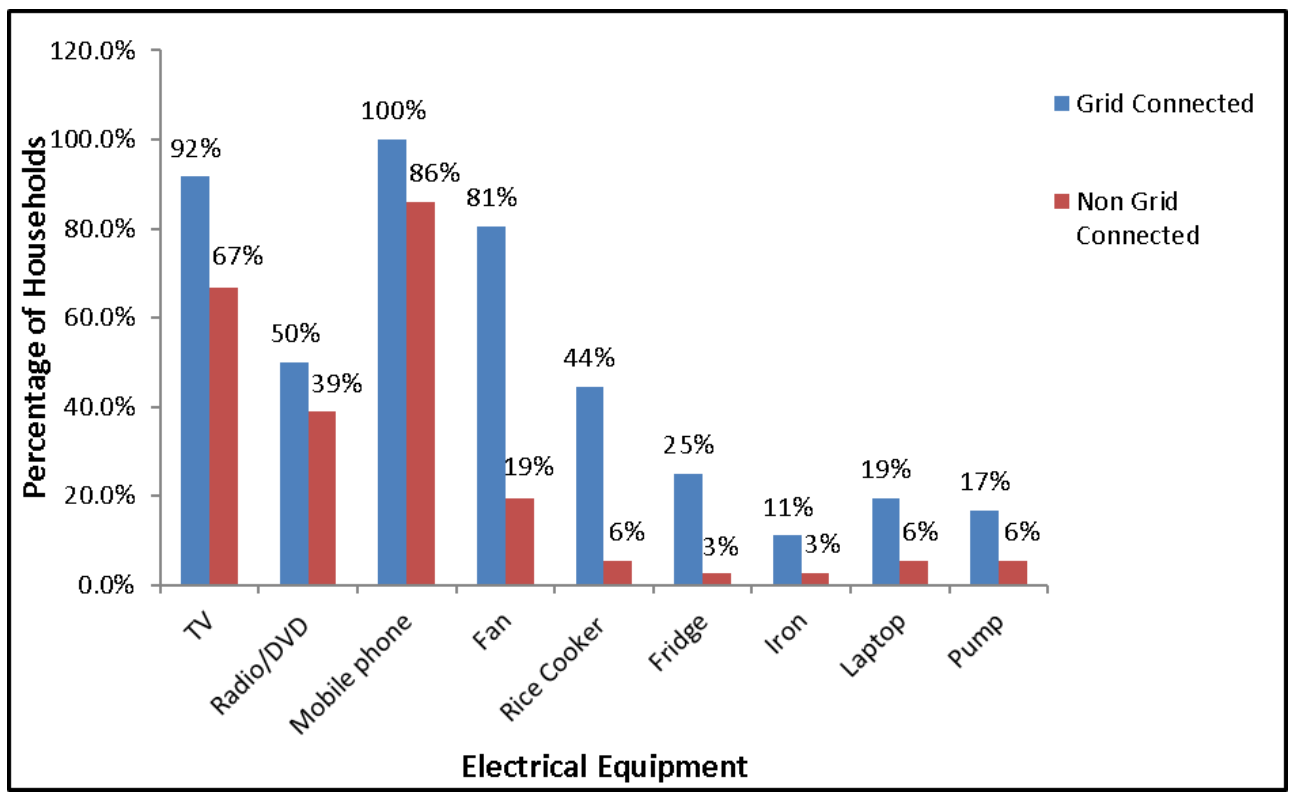

Fig. 3. Comparison of the electrical equipment.

$\mathrm{TV}$, radio/DVD player/speakers, and mobile phones were the most common equipment in both types of households. However, equipment such as fan, rice cooker, refrigerator, laptop, and water pump were more common in the grid-connected households as compared to non grid connected ones. From the survey, it also emerged that for most non grid 
connected households TV, fan and rice cooker ranks highest as the equipment they would most likely acquire if they were connected to the PLN grid.

\subsection{Cooking energy demand}

The residents of Bawean Island depend on more than one source of cooking energy, however, the main fuel is firewood. Firewood is easily and freely available to most households since the island has a significant forest cover.

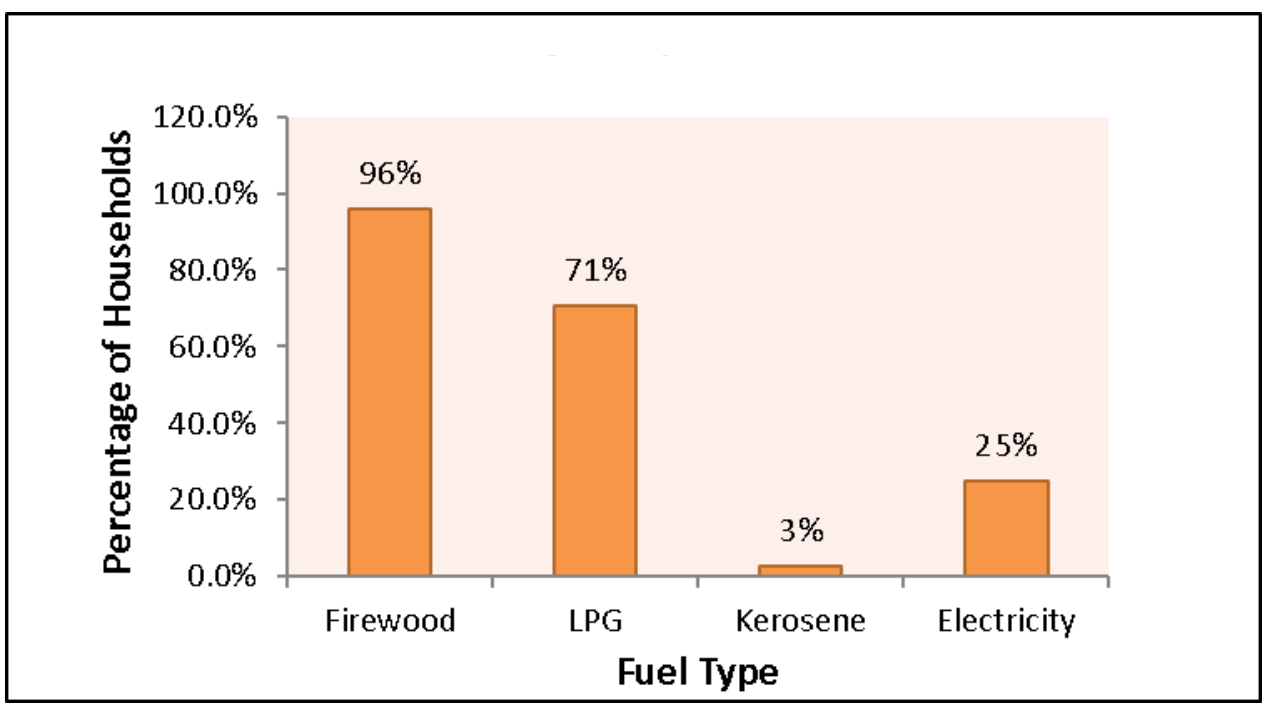

Fig. 4. Sources of cooking energy in the households.

Whereas $96 \%$ of the sampled households used firewood for cooking, $71 \%$ of the total households sampled also had and used LPG. This is remarkable given the remoteness of the Island and shows that the effort that the government of Indonesia has put towards increasing the uptake of LPG for cooking is yielding positive results

\section{Results and Discussion}

The proposed hybrid power system will be based on a combination of renewable energy sources and diesel generator. The design and optimization of this system were done using HOMER software; time step simulation software used for designing and analyzing the technical and financial viability of a power system based on different technologies and power sources. HOMER is also used to perform sensitivity analysis in order to optimize the system design based on different scenarios or conditions. 


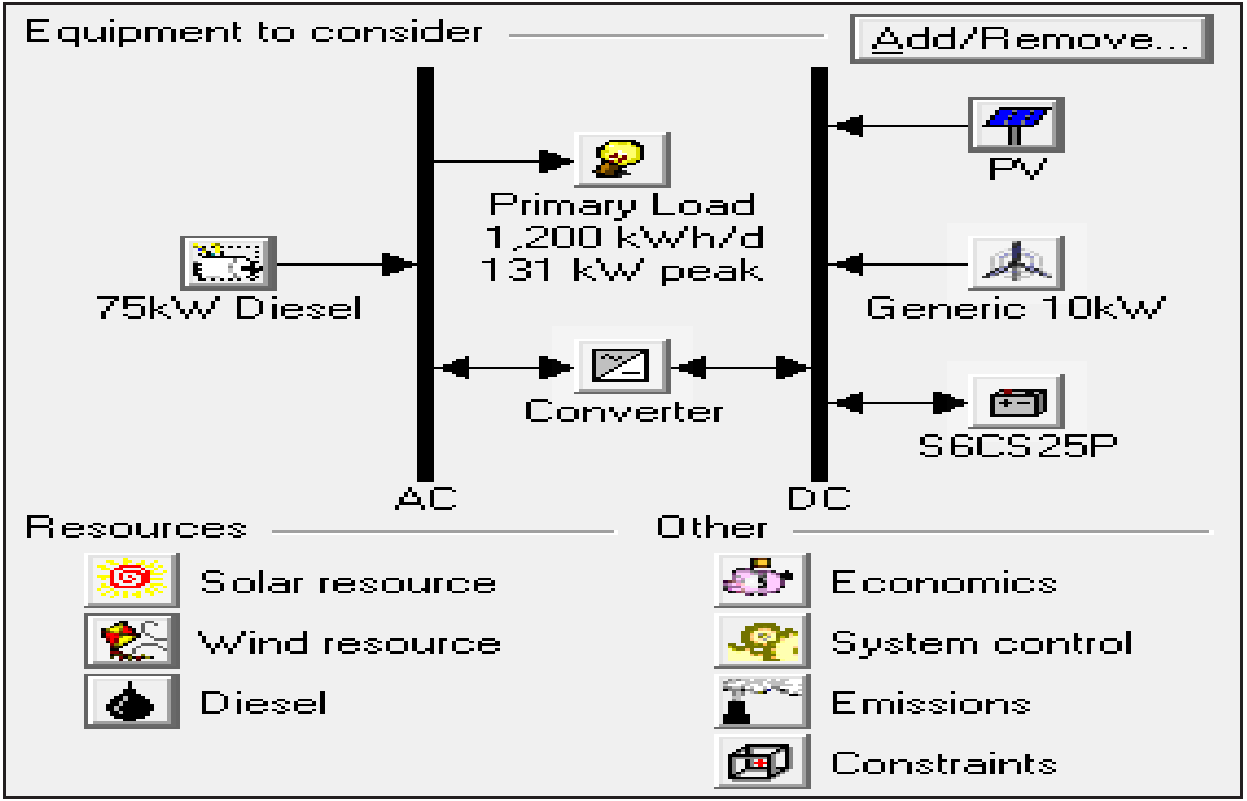

Fig. 5. Schematic of the proposed system.

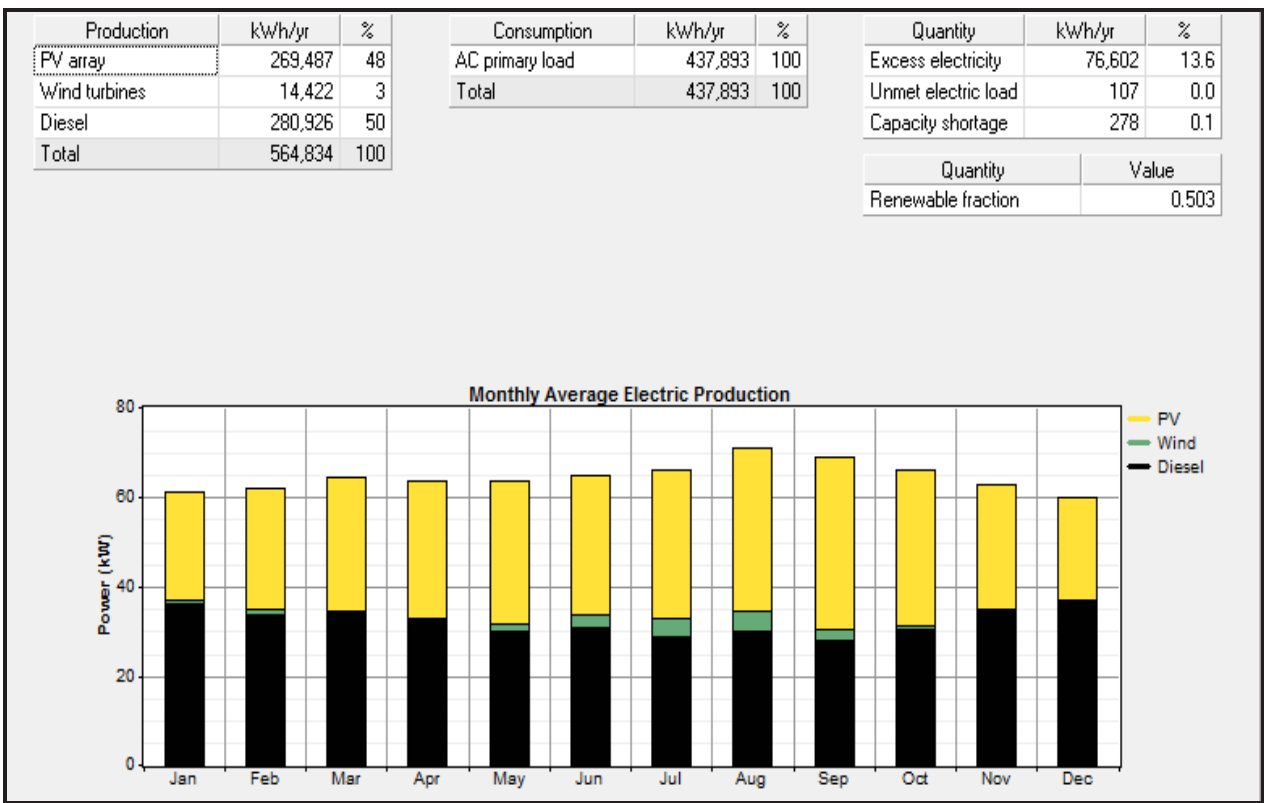

Fig. 6. Electrical power production by source.

It can be observed that it is expected that PV array will contribute the bulk (48\%) of the Renewable energy fraction over the entire year. Wind power output increases marginally in the windy months of June, July, and August. This mini grid electrical power system is expected to generate $565 \mathrm{MWh}$ per year against the expected load demand of $438 \mathrm{MWh}$ per y. For the optimum base system, the diesel generator set will operate for $4934 \mathrm{~h}$ per year; meanwhile the diesel generator set will be replaced six times over the project lifetime given that it has a lifetime of 15000 operating h. The other significant replacement cost in the project is that of batteries which will be done two times over the project lifetime. 


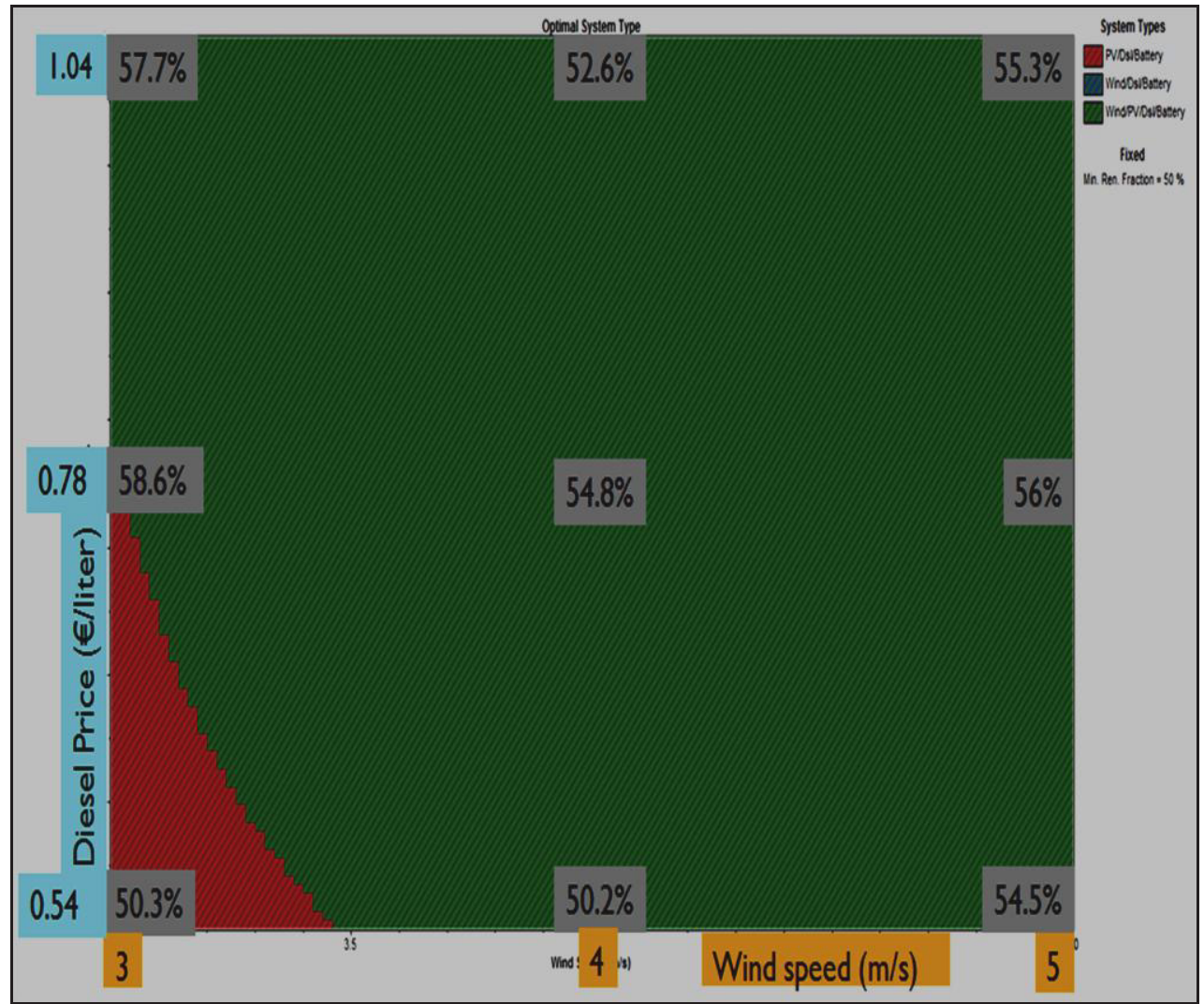

Fig. 7. Sensitivity Analysis for a hybrid system with $50 \%$ quota for RES.

The values in grey boxes of Figure 7 shows the expected fraction of renewable sources electrical production for the various optimum solutions based on the changes in the variables, that is, diesel price and average wind speed. For example, with the average wind speed being $4 \mathrm{~m} / \mathrm{s}$ and the diesel price being $€ 78$, then the optimum system chosen by HOMER will have $54.8 \%$ of the electrical production coming from renewable sources, that is both wind and solar PV for this case. This scenario is based on the simulation giving an optimal hybrid system with at least $50 \%$ electricity production from renewable energy sources (base case scenario). 


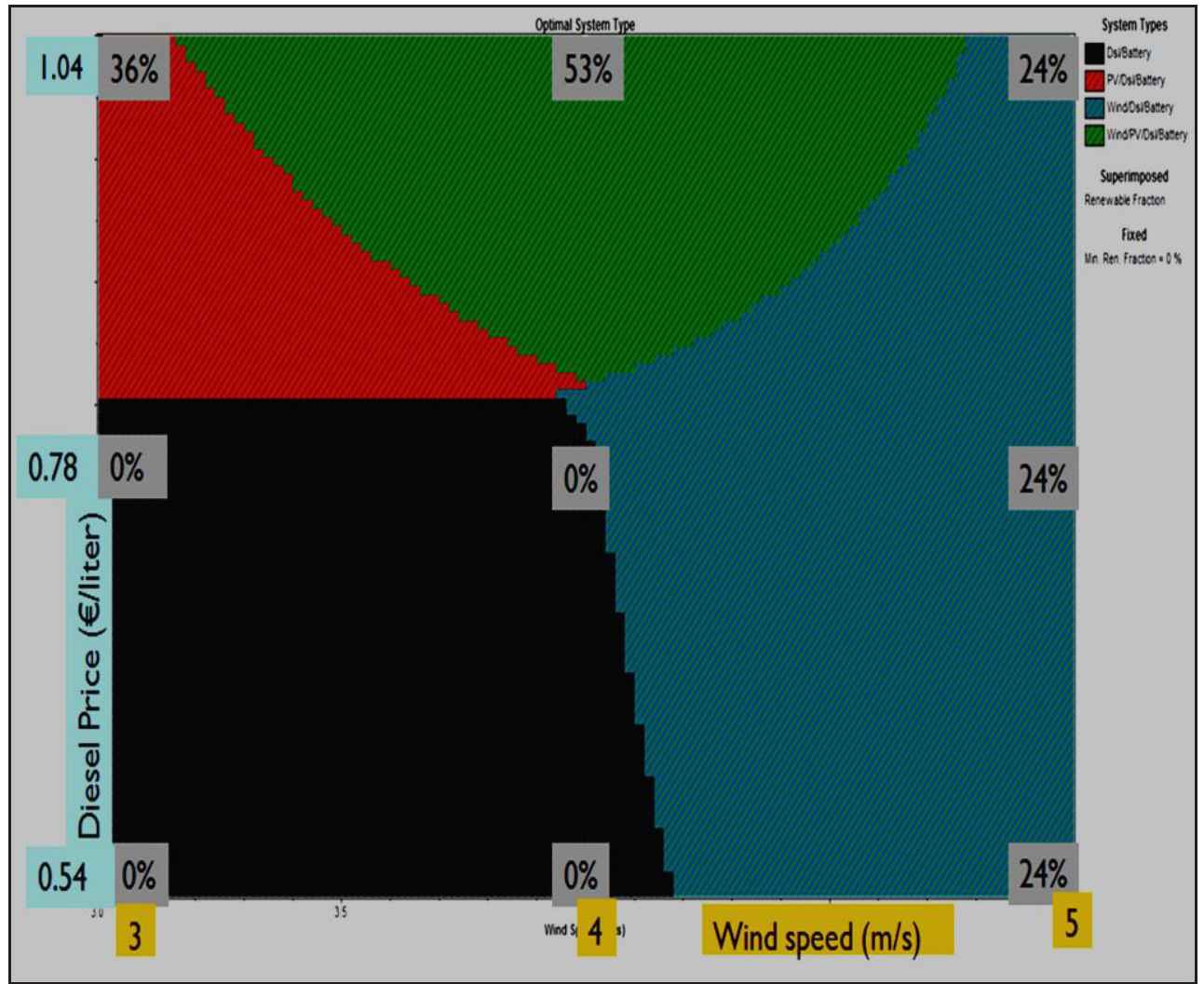

Fig. 8. Sensitivity Analysis for a hybrid system with $0 \%$ quota for RES.

A sensitivity analysis was also carried out on HOMER to determine the effect of a change in battery's lifetime on the levelised cost of energy (LCOE). The battery used in the simulation was assumed to have a conservative lifetime of $7 \mathrm{yr}$ even though the manufacturer's estimate is $12 \mathrm{yr}$. A sensitivity analysis was done to compare the LCOE for this base case as compared to if the battery had a lifetime of 5 yr or 10 y.r

\section{Conclusion}

This study was done to determine the current energy demand for the people living in Bawean Islands. Based on the average electricity consumption of $98 \mathrm{kWh}$ per month for the surveyed grid-connected households, a hybrid electrical power system was designed for Gili Timur Island. The proposed system was designed, simulated and optimized using HOMER software. A sensitivity analysis was also carried out on the optimum system to study the effects of variation in some of the system variables. HOMER suggests that for the expected peak load of $131 \mathrm{~kW}$, an optimum system will consist of $150 \mathrm{~kW}$ from PV array, two wind turbines each rated $10 \mathrm{~kW}$, a $75 \mathrm{~kW}$ diesel generator and batteries for storage. The initial capital needed to set up a hybrid electrical system is relatively high, and the residents of Gili Timur Island may not be in a position to raise the whole amount. It will, therefore, be a great idea if the local or central government could give a subsidized loan or grant towards this noble cause. This way the residents of Gili Timur Island can enjoy the benefits of a 24 h electricity grid just as their neighbors in main Bawean Island. 


\section{References}

1 Central Intelligence Agency. The world factbook: Indonesia [Online] from https://www.cia.gov/library/publications/the-world-factbook/geos/id.html (2013). [Accessed on 23 September 2013].

2 Consulate General of the Republic of Indonesia.Geography [Online] from http://indonesiavancouver.org/wp1/index.php/geography/ (2013). [Accessed 24 September 2013].

3 BPS (Central Bureau of Statistics) Gresik. Gresik dalam angka 2013 [Gresik in figures 2013]. BPS: Gresik (2013). pp 40-65. https://kupdf.com/download/gresik-dalamangka-2013_59f0a8efe2b6f5ab5ce375f1_pdf. [in Bahasa Indonesia]

4 P.F.A. Ogola, B. Davidsdottir, I.B. Fridleifsson. Renewable and Sustainable Energy Reviews, 15, 8:4067-4079 (2011). https://www.sciencedirect.com/science/article/pii/S1364032111002784

5 A. Brew-Hammond. Energy: the missing millenium development goal. In Energy for development resources, technologies, environment. F.L. Toht (Eds). Dordrecht: Springer (2012). pp. 35-43. http://www.springer.com/gp/book/9789400741614

6 R.A. Cabraal, D.F. Barnes, S.G. Agarwal. Annual Review of Environment and Resources, 30:117-144 (2005).

7 K. Kaygusuz. Renewable and Sustainable Energy Reviews, 16, 2:1116-1126 (2012). https://www.sciencedirect.com/science/article/pii/S1364032111005491

8 British Petroleum (BP). BP Statistical Review of World Energy [Online] http://www.bp.com/en/global/corporate/about-bp/statistical-review-of-world-energy2013.html (2013). [Accessed on 25 September 2013]

9 International Institute for Sustainable Development (IISD). A citizens' guide to energy subsidies in Indonesia. [Online] from http://www.iisd.org/gsi/sites/default/files/indonesia_czguide_eng_update_2012.pdf (2012). [Accessed on 23 September 2013].

10 International Institute for Sustainable Development (IISD). A Citizens' Guide to Energy Subsidies in Indonesia [Online] from http://www.iisd.org/gsi/sites/default/files/indonesia_czguide_eng_update_2012.pdf (2012). [Accessed on 23 September 2013].

11 International Energy Agency. World energy outlook 2012. [Online] from http://www.iea.org/publications/freepublications/publication/English.pdf (2012). [Accessed on 2 September 2013]

12 International Energy Agency. “World Energy Outlook 2012." iea.org. November, 2012. http://www.iea.org/publications/freepublications/publication/English.pdf (accessed on 10 September 2013)

13 International Energy Agency (IEA). Energy for all: Financing access for the poor. [Online] from http://www.iea.org/papers/2011/weo2011_energy for_all.pdf (2011). [Accessed on 6 October 2013]. 